\title{
Method of Payment and Accessibility to Healthcare in Urban Areas: Case of the Health District of Kisanga in the Democratic Republic of Congo
}

\author{
Ngolo Kwete Matthieu', Chuy Kalombola Didier'1, Kimba Mukanya Pascal1, \\ Matungulu Matungulu Charles ${ }^{2}$, Ilunga Kandolo Simon ${ }^{2 *}$, Mashini Ngongo Ghislain ${ }^{1}$, \\ Chenge Mukelenge Faustin', Mwembo Tambwe Albert1, Luboya Numbi Oscar ${ }^{1}$ \\ ${ }^{1}$ Faculty of Medicine, University of Lubumbashi, Lubumbashi, The Democratic Republic of the Congo \\ ${ }^{2}$ School of Public Health, University of Lubumbashi, Lubumbashi, The Democratic Republic of the Congo \\ Email: *silungak@gmail.com
}

How to cite this paper: Matthieu, N.K., Didier, C.K., Pascal, K.M., Charles, M.M., Simon, I.K., Ghislain, M.N., Faustin, C.M., Albert, M.T. and Oscar, L.N. (2021) Method of Payment and Accessibility to Healthcare in Urban Areas: Case of the Health District of Kisanga in the Democratic Republic of Congo. Open Access Library Journal, 8: e7712.

https://doi.org/10.4236/oalib.1107712

Received: June 29, 2021

Accepted: August 29, 2021

Published: September 1, 2021

Copyright $\odot 2021$ by author(s) and Open Access Library Inc.

This work is licensed under the Creative Commons Attribution International License (CC BY 4.0).

http://creativecommons.org/licenses/by/4.0/

\begin{abstract}
Introduction: Improving health conditions in poor countries should be a priority in development policies, not only because health problems are an integral dimension of poverty, but also because there is no access to development without work and no longer to a work without health. Method: We carried out a cross-section on accessibility to care in the Kisanga health zone with the aim of improving access to health care. Our data was collected based on a questionnaire as well as an interview. We used the Epi Info software for analysis and data recording. Results: Regarding the gender of heads of household, we observed a predominance of women (52.7\%); the Protestant religion was in the majority (29\%); households spent an average of $\$ 170$ for care; payment for care as well as discrimination were the determinants of access to care $(\mathrm{P}<0.0001)$. Conclusion: It is imperative to organize the health service and institute risk sharing in terms of third-party payment to promote access to health care, which is a condition for the emergence of any nation.
\end{abstract}

\section{Subject Areas \\ Health Policy, Public Health}

\section{Keywords}

Health Care, Accessibility, Mode of Payment, Kisanga 


\section{Introduction}

Continuity of care implies that the resources for the services that provide them, including financial resources, are permanently available. To this end, the financing of health care services should be predictable, stable, and sufficiently [1].

The use of basic health services is one of the key factors promoting better health of populations [2].

The payment of health care is supported by arguments of ethics and professional conduct, political philosophy (role of the state) and economics, for the sustainability of services [1]. The payment of care by their users or beneficiaries is of paramount necessity. On the one hand, it makes it possible to empower them, and on the other hand, it makes it possible to collect or collect the income necessary to finance health services. In Africa, the payment of healthcare by users is based on the reform plan called the Bamako initiative [1].

In fact, towards the 1980s after the departure of most of the colonizers from African countries, they who brought progress and resources by ensuring free health care, the state coffers were empty, the hope of health development tended to disappear, structural weaknesses were coming to light, and health structures had been left to their own devices, without drugs and with unpaid staff [1].

To "save" and revitalize the primary health care (PHC) strategy, two major events were held in 1987. First, an interregional meeting of the world health organization (WHO) was held in Harare (Zimbabwe) where African countries subscribed to the health district approach as a model for implementing PHC. A month later, the 37th session of the WHO regional committee was held in Bamako, Mali, at which African health ministers launched a reform plan called the "Bamako Initiative" (IB), in the presence of the Director-General of WHO and the Executive Director of UNICEF [1]. The IB aimed at a sustainable solution to the provision of financial resources to health services, relying, among other things, on the financial participation of the population to finance the health services and in the management of the services intended for them.

The objectives of establishing this financing system (IB) for health services include cost recovery, user empowerment, continuity, integration, accessibility, rationalization and relative autonomy of care and health facilities [1].

There are multiple financing systems, the criteria of which are the net income of users, the ease of setting up the system, the effects on care services, the effects on equity, and the effects on community participation [3].

In Developing Countries in general and in particular the health district of $\mathrm{Ki}$ sanga, accessibility to the health care system, especially basic and of high quality, poses enormous problems and difficulties and needs to be addressed a major concern of both national and provincial government.

The use of basic health services is one of the key factors promoting the better health of populations. The literature indicates that the analysis of the determinants of demand for care is extremely important for the formulation of policies and strategies in the health sector but also to ensure effective use of services and 
to improve the quality of services. It is also important for designing strategies capable of ensuring the sustainability of the financing of a health program [4]. As in most African countries, from the end of the 1970s with the debt crisis and during the 1980s, which were characterized by weak progress in health indicators, the idea was established that the decentralization of care could be part of the solution. This is how Rwanda adopted the primary health care strategy to promote the health of its population [2]. In 1995, with the aim of promoting quality, acceptable and accessible health care to the population, the country reformed the health system, in accordance with the Lusaka Declaration, which was adopted by the Government of National Union in 1996 [5].

WHO says that each year, more than 150 million people in 44 million households face catastrophic expenses when seeking treatment [6].

In Rwanda, in order to ensure the access of the Rwandan people to a healthy life and enable them to be socially and economically productive, the government has put in place the policy and continues to promote mutualist initiatives in order to guarantee equity in the distribution of health care and services, community solidarity, ipso facto financial accessibility to health care [7].

In Togo, new health and social protection policies were initiated between 2011 and 2015 with a view to solving the problem of catastrophic health spending. However, despite its initiatives and efforts, the contribution of households to the financing of health care remains substantial in this country. A survey conducted in 2015 of 2400 households on the ability to pay and total household expenditure shows that $7 \%$ (threshold of $40 \%$ ) of households have made catastrophic expenditure measured against non-food expenditure. This study maintains that at this threshold, Togolese households at risk allocate $60 \%$ of their total monthly expenditure to health care [8].

Retrospective study of health spending using data obtained from household surveys reveals that globally, 808 million people in 2010 incurred catastrophic health expenditure [9]. With regard to our study, our research purpose is to find out whether households in the Kisanga health District face catastrophic health expenditure while using health services.

\section{Methodology}

We conducted a cross-sectional study over the period from January to June 2018.

This study was carried out in the health district of Kisanga in the Democratic Republic of Congo in the province of Haut Katanga in the Democratic Republic of the Congo.

This health district has 11 health areas with an estimated population of 239,290 inhabitants in 2018. This population lives mainly from petty trade and agriculture. The most common illnesses include malaria, tuberculosis, HIV-AIDS infection, acute respiratory infections, and simple diarrhea. On a technical level, this ZS had a General Reference Hospital and around 75 public and mostly pri- 
vate first-line health facilities. The study population is made up of heads of households.

Sampling: The level of use of curative care services considered normal is 50 new cases/inhabitants per year, according to the health standards in force in the DRC [10]. We used Non-Probability Sampling and 501 households were chosen for our study.

Data collection: a pre-tested questionnaire was sent to each household.

Data analysis: The data and encoded in Excel then analyzed on correctly completed questionnaires were analyzed and coded. Data entry was performed by an entry operator in an entry mask created in Excel 2013. Statistical analysis of the data was carried out using Epi Info 7.6.2.2 and Excel 2013 software.

Conflict of Interest: No conflict of interest has been declared.

\section{Results}

The female sex was predominantly represented with $52.7 \%$, the age group between 20 and 34 years was in the majority and the maximum expenditure was between 12.5 and 25 USD (Table 1).

Among the respondents, the liberal profession was in the majority $(49.09 \%)$ and the Protestant religion was in the majority (58.18\%) (Table 2).

Table 1. Socio-demographic characteristics.

\begin{tabular}{|c|c|c|}
\hline Variables & Frequency & Percentage \\
\hline \multicolumn{3}{|c|}{ Sex } \\
\hline Male & 237 & 47.3 \\
\hline Female & 264 & 52.7 \\
\hline \multicolumn{3}{|c|}{ Age } \\
\hline$\leq 19$ & 11 & 2.2 \\
\hline $20-34$ & 212 & 42.32 \\
\hline $35-49$ & 197 & 39.32 \\
\hline $50-64$ & 71 & 14.17 \\
\hline $65-73$ & 10 & 2 \\
\hline \multicolumn{3}{|c|}{ Expenses (USD) } \\
\hline$<12.5$ & 86 & 17.2 \\
\hline $12.5-25$ & 170 & 33.9 \\
\hline $26-37.5$ & 98 & 19.6 \\
\hline $38-50$ & 52 & 10.4 \\
\hline$>51$ & 95 & 19 \\
\hline Total & 501 & 100 \\
\hline
\end{tabular}


Figure 1 indicates that 438 or $87.4 \%$ of our respondents had access to curative care against 63 or $12.6 \%$ had access to other care.

Figure 2 shows us that 219 or $43.81 \%$ of our respondents had attested that the reception of nursing staff was good. Less expensive health care follow up with 165 or $32.99 \%$.

Figure 3 indicates that in $74.1 \%$ of cases the households used the direct payment method our respondents. Their method of payment was direct and against indirect method of payment $25.9 \%$.

Table 3 shows the result about who pays for health care in the household.

Table 4 shows that there is a statistically significant association between the method of payment, negative discrimination and accessibility to care ( $\mathrm{P}$-value $<$ $0.05)$ while there is none between accessibility to care and equality of care (P-value $>0.05)$.

Table 2. Socio-demographic characteristics (Continued).

\begin{tabular}{ccc}
\hline Variables & Frequency & Percentage \\
\hline Employer & the main activity of the head of household & \\
State worker & 108 & 21.82 \\
Independent & 23 & 13.64 \\
Liberal & 246 & 4.55 \\
Private employee & 37 & 49.09 \\
Without occupation & 18 & 7.27 \\
& 159 & 3.64 \\
Catholic & 18 & 31.82 \\
Revival Church & 9 & 3.64 \\
Muslim & 292 & 1.82 \\
Protestant & 23 & 58.18 \\
Jehovah's Witness & 501 & 4.55 \\
Total & & 100
\end{tabular}

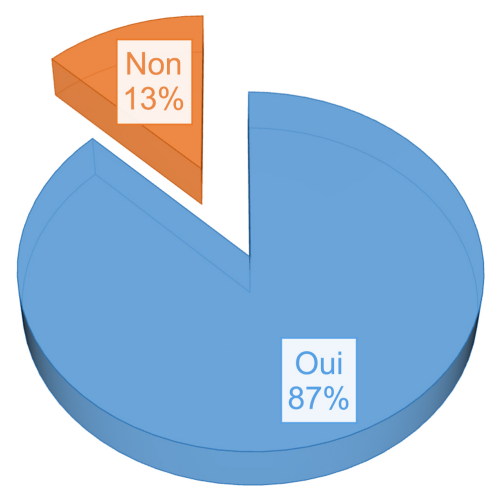

Figure 1. Accessibility to curative care. 
Table 3. Distribution of respondents according to the person paying for health care in the household.

\begin{tabular}{ccc}
\hline Person who pays for care in case of illness & Frequency & Percentage \\
\hline Head of household & 114 & 22.8 \\
Other & 387 & 77.2 \\
Total & 501 & 100 \\
\hline
\end{tabular}

Table 4. Association between discrimination, payment method, equality and accessibility to curative care.

\begin{tabular}{|c|c|c|c|c|}
\hline \multirow{2}{*}{ Variables d'étude } & \multicolumn{4}{|c|}{ Accessibility } \\
\hline & Oui & Non & OR (CI 95\%) & $\mathrm{p}$ \\
\hline \multicolumn{5}{|l|}{ Discrimination } \\
\hline \multirow[t]{2}{*}{ Yes } & $429(88.8)$ & $54(11.2)$ & & \\
\hline & & & $7.9(3.0-20.9)$ & $0.0000002^{\star}$ \\
\hline No & $9(50.0)$ & $9(50.0)$ & & \\
\hline \multicolumn{5}{|l|}{ Payment method } \\
\hline \multirow[t]{2}{*}{ Direct payment } & $336(90.6)$ & $35(9.4)$ & & \\
\hline & & & $2.6(1.5-4.5)$ & $0.000342^{*}$ \\
\hline Indirect payment & $102(79.7)$ & $28(20.3)$ & & \\
\hline \multicolumn{5}{|l|}{ Equal care } \\
\hline \multirow[t]{2}{*}{ No } & $427(87.7)$ & $60(12.3)$ & & \\
\hline & & & $1.9(0.5-7.2)$ & $0.31088^{\star *}$ \\
\hline Yes & $11(78.6)$ & $3(21.4)$ & & \\
\hline
\end{tabular}

*: Significant association; ${ }^{* *}$ : Association not significant.

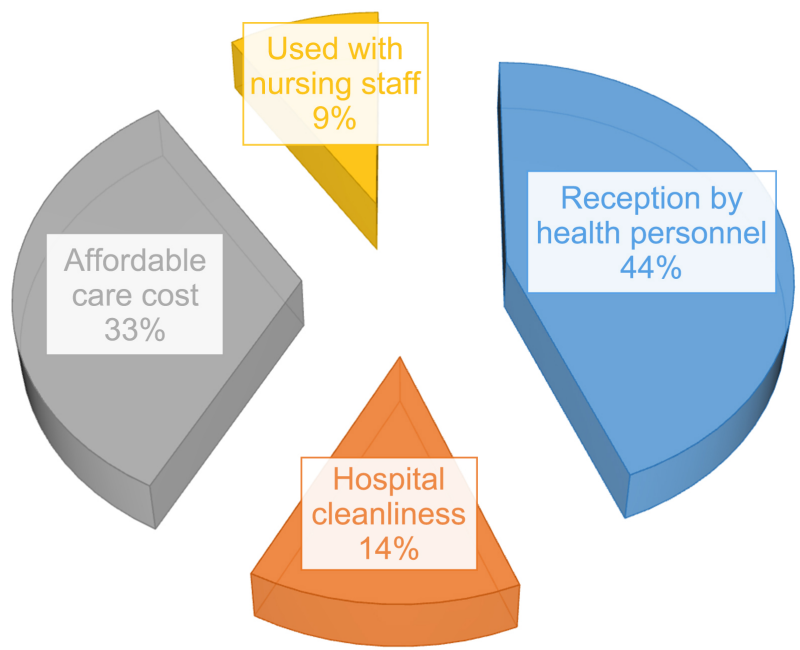

Figure 2. Respondents and factors influencing access to curative care. 


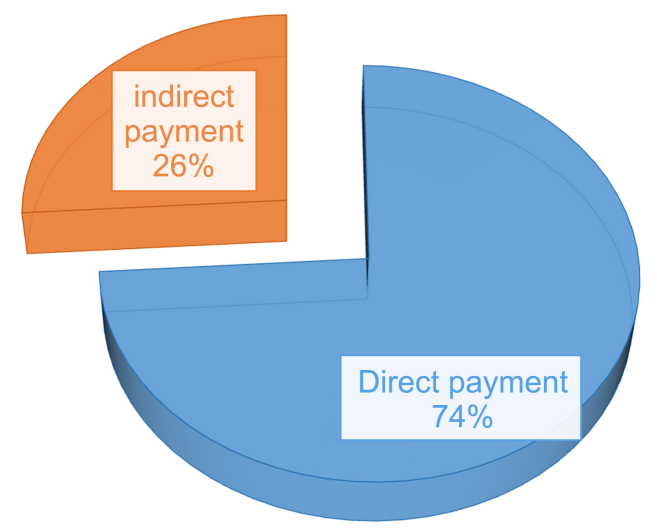

Figure 3. Distribution of respondents according to the method of payment for health care.

\section{Discussion}

\subsection{Socio-Demographic Characteristics}

In $49.1 \%$ of cases (Table 2), the heads of households occupied liberal functions versus those who were without occupation (3.6\%); Protestants were in the majority (58.2\%) against Muslims (1.8\%). In some studies on the factors determining access to health care, farmers were in the majority [11].

\subsection{Improving Accessibility to Curative Care}

We observed that 219 or $43.81 \%$ of our respondents had attested that the reception of nursing staff was good, followed by less expensive health care with 165 or $32.99 \%$ (Figure 2). Some authors believe that the improving access to healthcare also requires the establishment of a clear, uniform and appropriate pricing system [12].

\subsection{Method of Payment for Health Care}

In $74.1 \%$ of cases, households used the direct payment method our respondents, their payment method was direct as shown in Figure 3. In the DRC, only $2.4 \%$ of the working populations enjoy social security coverage, moreover, partial and $82 \%$ of the populations say they are unable to pay for their health care [13]. In many OECD countries, the progressivity of these indirect payments is, in reality, more than enough to compensate for the degression of direct payments. [14].

\subsection{Source of Payment for Health Care in the Household}

In $77.2 \%$ of cases, the managers were not able to pay for their care and they were honoured by third parties (family member, church, neighbours, etc.). Our results do not match those of Mashini Ngongo and Kabyla Ilunga who found that housewives contribute more than $70 \%$ to health care [15] [16].

\subsection{Determinants of Accessibility to Curative Care}

Discrimination, as well as the method of payment determine access to healthcare 
in Kisanga $(\mathrm{P}<0.001)$ while equality of care had no statistically significant link with access to healthcare $(\mathrm{P}>0.001)$. In the DRC, household income is one of the criteria used by the populations to define the choice of their health care [11]. Thus, households with a higher income will seek care in private structures, and people with a low income will seek care in public structures [17]. Some authors have found that household financial income is a factor in access to health care, but not in the decision to join the mutual insurance company [18] [19].

\section{Conclusions}

We observed that in socio-demographic terms, female heads of household were in the majority (52.7\%). The age group between 20 and 34 years was the majority, i.e. $212(33.9 \%)$ and most households spent between $\$ 12.5$ and $\$ 25$ per illness episode (33.9\%); while 438 or $87.4 \%$ of our respondents had access to curative care against 63 or $12.6 \%$ had access to other care.

Since health is not a right, access to health care is required by universal health coverage and the politico-administrative authorities as well as civil society must activate the lever so that every citizen has access to care. Health when he needs it and without suffering from his pocket.

\section{Acknowledgement}

Our thanks go to each of the authors who have deigned to contribute to this work from the conception, the analysis as well as the design. We especially thank professors Mashini Ngongo Ghislain, Chenge Mukelenge Faustin, Mwembo Tambwe Albert and Luboya Numbi Oscar for the design; Ngolo Kwete Matthieu, Chuy Kalombola Didier and Kimba Mukanya Pascal (Members of the scientific corps) for the design and data collection.

We also send our thanks to Professor Ilunga Kandolo Simon and, to the head of work Charles Matungulu Matungulu for the data analysis as well as the English translation of this manuscript.

\section{Conflicts of Interest}

The authors declare no conflicts of interest.

\section{References}

[1] Dugas, S. and Van Dormael, M. (2003) La construction de la médecine de famille dans les pays en développement. http://lib.itg.be/pdf/itg/2003/2003shso0001.pdf

[2] Munyamahoro, M. and Ntaganira, J. (2012) Déterminants de l'utilisation des services de sante par les ménages du district de rubavu. The Rwanda Medical Journal, 69, 24-31.

[3] Criel, B. and Kegels, G. (1997) A Health Insurance Scheme for Hospital Care in Bwamanda District, Zaire: Lessons and Questions after 10 Years of Functioning. Tropical Medicine \& International Health, 2, 654-672. https://doi.org/10.1046/j.1365-3156.1997.d01-349.x

[4] OMS (2019) La qualité des services de santé. 
https://www.who.int/servicedeliverysafety/

[5] WHO (2003) World Health Report 2002-Reducing Risks, Promoting Healthy Life Methods Summaries for Risk Factors Assessed in Chapter 4.

[6] OMS (2005) Système de financement de la santé: Comment réduire les dépenses catastrophiques.

[7] DSGAS and GTZ (2004) Enquête-ménages sur les besoins de santé de base en Province de Butare et Byumba (Rwanda), Kigali.

[8] Sanoussi, Y. and Ametoglo, M. (2019) Ampleur et déterminants des dépenses catastrophiques de santé: Cas des ménages togolais. https://www.semanticscholar.org/

[9] Wagstaff, A., et al. (2018) Articles Progress on Catastrophic Health Spending in 133 Countries: A Retrospective Observational Study. The Lancet Global Health, 6, 169-179. https://doi.org/10.1016/S2214-109X(17)30429-1

[10] Rdc-MiniSanté (2012) Normes de la zone de sante relatives aux interventions intégrées de sante de la mère, du nouveau-né et de l'enfant en République Démocratique du Congo. Volume 2: Soins obstétricaux d'urgence.

[11] Lubula, F., Chenge, F., Criel, B. and Mukalay, A. (2017) Organisation, Offre et demande des services de santé de qualité: 18ans d'Expériences des mutuelles de santé en Province du Sud Kivu/RD Congo. International Journal of Multidisciplinary and Current Research, 5, 3-4.

[12] Doumbouya, M.L. (2008) Accessibilité des services de santé en Afrique de l'Ouest: Le cas de la Guinée. https://halshs.archives-ouvertes.fr/

[13] Manzambi, K.J., Guillaume, M., Balula, S.M.P., Tshiama, K.E., Mayamba, K.J., Bruyère, O. and Reginster, J.Y. (2013) Etude des conditions de vie et d'accessibilité aux soins de santé de qualité des populations en situation de précarité, dans la zone de santé de Bandalungwa à Kinshasa (Congo) grâce à la micro-assurance sante en 2008. Revue d Epidémiologie et de Santé Publique, 12, 47-61.

[14] Wagstaff, A. (2002) Pauvreté et inégalités dans le secteur de la santé. Bulletin of the World Health Organization, 80, 97-105.

[15] Kabyla Ilunga, B. (2018) Economie de la santé. Work Paper, the University of Lubumbashi.

[16] Mashini, N.G. and Luboya, N.O. (2009) Systemes et politiques de santé. LUBUMBASHI.

[17] Dubois, F. (2001) Les déterminants de la participation aux mutuelles de santé: Étude appliquée à la mutuelle Leeré Bolem de Zabré. Université de Liège, Liège.

[18] Letourmy, A. (2000) Les mutuelles de santé en Afrique: Conditions d'un développement. Afrique Contemporaine, 3, 230-240.

[19] Haddad, S. (1992) Utilisation des services de santé en pays en développement, in Institut d'analyse des systèmes biologiques et socio-économiques. Université de Lyon Claude Bernard, Lyon. 